ADAM BANIECKI

(Archiwum Państwowe we Wrocławiu Oddział w Bolesławcu)

ANNA LASZUK

(Naczelna Dyrekcja Archiwów Państwowych w Warszawie)

\title{
FUNKCJE AKTOTWÓRCÓW NA PRZYKŁADZIE ARCHIWÓW PAŃSTWOWYCH. ROZWAŻANIA WSTĘPNE
}

\section{Słowa kluczowe}

funkcje, Records in Contexts, standard opisu, system informacji archiwalnej, tezaurus archiwistyki

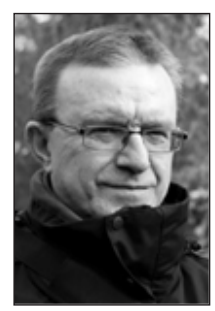

Adam Baniecki, historyk, archiwista, doktor nauk humanistycznych w zakresie historii. Od 1985 r. związany z archiwami państwowymi i archiwistyką. Wieloletni kierownik Archiwum Państwowego we Wrocławiu Oddział w Lubaniu (od 2014 w Bolesławcu_. Redaktor naczelny Naukowego Portalu Archiwalnego ArchNet, członek Zarządu Głównego Stowarzyszenia Archiwistów Polskich, członek zarządu Bolesławieckiego Klubu Taekwon-Do ITF w Bolesławcu. Autor publikacji z zakresu metodyki archiwalnej i standaryzacji w archiwach oraz publikacji z zakresu historii regionalnej Dolnego Śląska.

E-mail: baniecki@archiwa.net; ORCID ID: 0000-0002-7519-9494

Anna Laszuk, historyk, archiwista, dr nauk humanistycznych w zakresie historii. Od 1995 r. pracownik Naczelnej Dyrekcji Archiwów Państwowych. Początkowo zajmowała się tworzeniem systemu informacji archiwalnej, później metodyką opracowania zasobu archiwalnego. Członek zespołów naukowych i Centralnej Komisji Metodycznej. Autorka i redaktorka artykułów i publikacji z zakresu historii Podlasia, informacji archiwalnej i standaryzacji opisu archiwalnego.

E-mail: anial11@wp.pl; ORCID ID: 0000-0002-6494-2115

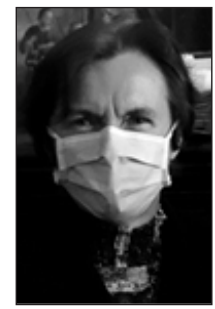




\section{Keywords}

functions, Records in Contexts, description standard, archival information system, archival thesaurus

\section{Streszczenie}

Przedstawienie przez Międzynarodową Radę Archiwów projektu nowego modelu opisu archiwalnego „Records in Contexts” sprawiło, że autorzy poszukują możliwości zastosowania tego modelu w polskim systemu informacji archiwalnej. Zwracają uwagę na brak w Polsce opracowań czy tezaurusa zawierającego usystematyzowane funkcje pełnione przez różne podmioty działające we wszelkich obszarach. Odwołują się do nielicznych przykładów z innych państw, w tym tezaurusa funkcji The Australian Governments' Interactive Functions Thesaurus, który był jedną z podstaw przygotowania Międzynarodowego standardu opisu funkcji ISDF i systemu Access to Memory AtoM, oraz późniejszego poradnika z Brytyjskiej Wspólnoty Narodów Strategies for Documenting Government Business: the DIRKS Manual. Następnie wskazują osiem określonych w ustawie o narodowym zasobie archiwalnym i archiwach podstawowych obszarów działalności archiwów państwowych, tzn. kształtowanie państwowego zasobu archiwalnego, gromadzenie, ewidencjonowanie, przechowywanie, opracowanie, zabezpieczenie i udostępnianie materiałów archiwalnych oraz prowadzenie działalności informacyjnej. Wstępnej częściowej analizie poddane zostały niektóre przepisy i dokumenty sporządzane w archiwach, tzn. jednolity rzeczowy wykaz akt (jrwa), wzór sprawozdania z działalności archiwum państwowego oraz Strategia Archiwów Państwowych na lata 2010-2020, jako źródła mogące dostarczyć informacji przy tworzeniu polskiego słownika funkcji, przynajmniej w zakresie działalności archiwów państwowych. Jako model teoretyczny, który można przy tych pracach wykorzystać, wskazany został Tezaurus archiwistyki, autorstwa Stanisława Nawrockiego. Opracowanie kończą pytania o możliwość zastosowania w Polsce podejścia do systemu informacji opartego na analizie funkcji i dokumentacji wytwarzanej w trakcie ich wykonywania, które są zachętą do podjęcia dyskusji nad kształtem systemu informacji o zasobie.

\section{Summary}

Functions of archives creators on the example of state archives. Preliminary considerations

The presentation by the International Council of Archives of the project of a new model of archival description "Records in Contexts" made the authors look for the possibility of using this model in the Polish system of archival information. They draw attention to the lack of studies or thesaurus in Poland containing systematized functions performed by various entities operating in all areas. They refer to a handful of examples from other countries, including the function thesaurus for The Australian Governments' Interactive Functions Thesaurus, which was one of the foundations for the preparation of the International Standard for Describing Functions ISDF and Access to Memory AtoM, and the later guidebook from the British Commonwealth - Strategies for Documenting Government Business: the DIRKS Manual. 
Then, they indicate the eight basic areas of activity of state archives specified in the Law on the national archival holdings and archives, i.e. shaping the state archival holdings, collecting, inventorying, storing, processing, securing and providing access to archival materials, and conducting information activities. Some regulations and documents prepared in the archives were subject to a preliminary partial analysis, i.e. the uniform substantive records classification scheme, the model report on the activities of the state archives and the Strategy of the State Archives for 2010-2020, as sources that can provide information when creating the Polish dictionary of functions, at least in the scope of the activities of state archives. As the theoretical model that can be used in these works, the Archival Thesaurus by Stanisław Nawrocki was pointed out. The study ends with questions about the possibility of applying in Poland an information system approach based on the analysis of functions and records produced during their performance, which are an incentive to discuss the shape of the system of information about the holdings.

$\mathbb{M}$ ędzynarodowy standard opisu funkcji ISDF jest jedynym standardem opisu opracowanym przez Międzynarodowej Radę Archiwów, w którego przetłumaczonej na język polski wersji nie zostały dodane polskie przykłady ${ }^{1}$. Funkcja jest w tym standardzie definiowana jako „Całość celów lub zadań wysokiego poziomu przynależnych jednostce organizacyjnej z mocy prawa, polityki lub będących wynikiem sprawowanego mandatu. Funkcje mogą być podzielone na skoordynowane całości operacyjne, takie jak podfunkcje, procedury administracyjne, działania, zadania lub operacje"2. Przyczyną braku polskich przykładów był przede wszystkim brak opracowań teoretycznych czy praktycznie stosowanych słowników i tezaurusów, które posłużyłyby jako listy referencyjnych terminów ${ }^{3}$. Także w wielu innych krajach nie wypracowano odpowiednich narzędzi klasyfikacyjnych ${ }^{4}$.

${ }^{1}$ ISDF. Międzynarodowy standard opisu funkcji, tłum. A. Baniecki, Warszawa 2017. https://www.archiwa.gov.pl/files/ISDF.pdf (dostęp 08.08.2020).

2 Tamże, s. 9.

${ }^{3}$ Opiniowanie polskiej wersji na forum Centralnej Komisji Metodycznej opisała A. Laszuk, Zagadnienia teoretyczne i praktyczne a rekomendacje Centralnej Komisji Metodycznej kadencji 2013-2016, [w:] Metodyka i standardy opracowania archiwalnego. Rzeczywistość i potrzeby, red. I. Mamczak-Gadkowska, K. Stryjkowski, Poznań 2019, s. 25-26.

${ }^{4}$ O braku wykorzystania funkcji świadczy pośrednio fakt, iż właśnie standard ISDF nie został uwzględniony, mimo wstępnych planów, w systemie Europejskiego Portalu Archiwalnego, por. A. Laszuk, Europejski Portal Archiwalny - efekt wspótpracy i działania opartego na standardach międzynarodowych, [w:] Archiwa Polski i Europy - wspólne dziedzictwo, różne doświadczenia, red. A. Kulecka, Warszawa 2017, s. 23-34. 
Na tym tle wyjątkowo prezentuje się The Australian Governments' Interactive Functions Thesaurus (AGIFT) - trzypoziomowy hierarchiczny tezaurus, obejmujący funkcje publiczne pełnione przez jednostki organizacyjne różnego poziomu - rządowe i lokalne. Na najwyższym poziomie ujęto w nim 26 podstawowych funkcji zebranych w słownik o nazwie Keyword AAA określających ogólną terminologię przeznaczoną do klasyfikowania i indeksowania obszarów właściwości państwa ${ }^{5}$. Podstawowa klasyfikacja zbudowana została w oparciu o zasady zawarte w australijskiej normie AS ISO 15489 - Records management, u podstawy której znalazła się australijska systematyka działalności jednostek organizacyjnych ${ }^{6}$. Zastąpiono tam klasyfikację informacji według treści tematycznej klasyfikacją funkcjonalną ${ }^{7}$. Owe podstawowe funkcje (nazwane za pomocą rzeczowników odczasownikowych) ${ }^{8}$ znajdujących się na szczycie hierarchicznych trzy- lub czteropoziomowych opisów aktywności odpowiednich podmiotów (np.: archiwów historycznych, bibliotek czy muzeów) tworzą hierarchicznie zbudowany tezaurus kontrolowanego słownictwa opisującego funkcje konkretnych jednostek organizacyjnych. W opisie każdej z nich znajdują się etykiety osadzające terminologię AGIFT w systemie Simple Knowledge Organization System (SKOS Prosty System Organizacji Wiedzy). W praktyce oznacza to, że AGIFT jest gotowym produktem, który może być natychmiast włączony do systemów opisu archiwalnego, jak np. do Access to Memory AtoM. W efekcie użytkownicy AtoM-u w prosty sposób mogą dołączać hasła wzorcowe funkcji do opisów archiwalnych, czyniąc wyszukiwanie informacji naukowej mocno klarownym i zunifikowanym?

${ }^{5}$ Wśród nich znajdują się np.: sprawy kultury (cultural affairs), nauka, zasoby naturalne, turystyka i handel. Keyword $A A A$ został opracowany przez State Records Autority of New South Wells, a National Archives na ich bazie opracowały wersję udostępnioną całej Brytyjskiej Wspólnocie Narodów. https://data.naa.gov.au/def/agift/AGIFT.html (dostęp 08.08.2020).

${ }^{6}$ Overview of Classification Tools for Records Management, July 2003, s. 6. http://naa. gov.au/Images/developing-a-thesaurus_tcm16-47228.pdf (dostęp 27.10.2020)

7 Szerzej patrz: Overview of Clasification. Tools for Records Management. National Archives of Australia, July 2003, s. 7., https://www.naa.gov.au/sites/default/files/2019-10/ classifcation-tools.pdf (dostęp 27.10.2020).

${ }^{8}$ Funkcje, działania i transakcje określane są za pomocą czasowników, ponieważ dokumentują wykonywanie czynności, do których powołana jest jednostka organizacyjna.

9 Szczegółowe informacje na ten temat przedłożono w 2020 r. Naczelnemu Dyrektorowi Archiwów Państwowych. Patrz: „Raport końcowy z realizacji projektu badawczego wdrożenia systemu Access to Memory AtoM w Archiwum Państwowym we Wrocławiu w latach 2012-2016 sporządzony pod kątem optymalizacji funkcji archiwów państwo- 
W Polsce pewnych analogii na tym najwyższym poziomie funkcjonalnym można się doszukiwać w ustawie o działach administracji rządowej ${ }^{10}$, a także w Polskiej Klasyfikacji Działalności ${ }^{11}$. Nie powstała jednak podobna systematyka funkcji, która umożliwiłaby dopasowanie ich do typologii proponowanej w ISDF, dołączonej do zasad opisu elementu 5.1.1. - Typ funkcji, tzn. Funkcja, Podfunkcja, Proces administracyjny, Czynność, Zadanie, Operacja/transakcja ${ }^{12}$. Należy też zwrócić uwagę, że stosowanie AGIFT, nie ogranicza się do administracji rządowej czy samorządowej, ale jest dostępny dla wszelkich podmiotów, jednostek organizacyjnych funkcjonujących w obszarze społecznym. Korzystanie z AGIFT jest dobrowolne. Nie oznacza to, że jednostki organizacyjne nie wykorzystujące tego tezurusa nie wywiązują się ze swoich zadań. Analiza funkcjonalna służy usprawnieniu zarządzania dokumentacją oraz łatwym dostępem do informacji.

Podstawowym narzędziem do budowy hierarchicznych struktur funkcji wraz z niższymi poziomami (wspomnianymi wyżej) wykorzystywanymi w krajach Brytyjskiej Wspólnoty Narodów jest tzw. DIRKS ${ }^{13}$. W 2012 r. doświadczenia anglosaskie zostały udostępnione także innym społecznościom archiwalnego świata. W czasie Międzynarodowego Kongresu Archiwów w Brisbane w Australii zaprezentowano podręcznik Archiwizacja klucz do dobrego zarzadzania ${ }^{14}$, okre-

wych (Drugi raport)" , oprac. dr Adam Baniecki i inż. Rafał Raczyński, s. 6. Registratura Naczelnej Dyrekcji Archiwów Państwowych (dalej RNDAP), DA.041.1.2020.

10 Ustawa z dnia 4 września 1997 r. o działach administracji rządowej t.j., „Dziennik Ustaw Rzeczypospolitej Polskiej" (dalej Dz.U.), 2020, poz. 1220. Jej art. 14.1. dotyczy działu „kultura i ochrona dziedzictwa narodowego”, który w 14 punktach obejmuje różne formy działalności kulturalnej, lecz żaden z nich nie wymienia archiwów. Ustęp 2. w tym artykule ma nietypowe dla materii działów administracji brzmienie, bowiem stanowi, że „Minister właściwy do spraw kultury i ochrony dziedzictwa narodowego sprawuje nadzór nad Naczelnym Dyrektorem Archiwów Państwowych”.

${ }^{11}$ Częściowo jest ona zgodna z Europejską Klasyfikacją Działalności, a dotyczy działania podmiotów gospodarczych. Wprowadzona została rozporządzeniem Rady Ministrów z dnia 24 grudnia 2007 r. w sprawie Polskiej Klasyfikacji Działalności (PKD), Dz.U., 2005, nr 251 poz. 1885.

${ }^{12}$ ISDF. Międzynarodowy standard, s. 14. W wersjach angielskiej (functions, subfunctions, business processes, activities, tasks or transactions) i francuskiej (fonctions sous-fonctions, procédures opérationnelles, activités, tâches ou transactions) zestawienie terminów jest takie samo w definicji i elemencie 5.1.1. Różnice obrazują potrzeby terminologiczne w Polsce.

13 Strategies for Documenting Government Business: the DIRKS Manual, July 2018, https://www.records.nsw.gov.au/recordkeeping/strategies-documenting-government-business\%3A-the-dirks-manual (dostęp 28.10.2020).

${ }^{14}$ L'archivage, clé d'une bonne gouvernance, Juillet 2012, zwany skrzynką z narzędziami (boüte à outils). Szerzej na temat tego poradnika w literaturze polskiej: A. Baniecki, 
ślony także jako „skrzynka z narzędziami”. Ta zbudowana modułowo pomoc przybliża, niekiedy upraszczając, skomplikowane procedury oparte na standardach i normach opisywanych DIRKS. Wersja francuska od angielskiej różnią się nieco z racji innych adresatów publikacji (wersja francuska skierowana była także do odbiorców Afryki frankofońskiej, francuskojęzyczna Kanada natomiast funkcjonuje $\mathrm{w}$ anglosaskim systemie).

Z punktu widzenia rozważanego tu zagadnienia funkcji archiwów, bardzo istotnym jest zastrzec i podkreślić fundamentalną dla zarządzania dokumentacją, budowy planu archiwizacji, jej opisu, wartościowania, decydowania o brakowaniu lub pozostawieniu, systematykę funkcji. Dzielą się one bowiem na funkcje podstawowe i funkcje wspierające ${ }^{15}$. Funkcje podstawowe to te, do których wykonywania została powołana dana jednostka organizacyjna. Podstawowe to znaczy takie, które są głównym celem jej działalności, choć oczywiście może je dzielić z innymi podmiotami. Np.: podstawowe zadania archiwów państwowych wynikają z ustawy archiwalnej. Funkcje wspierające natomiast to takie, których wykonanie jest niezbędne dla funkcjonowania organizacji, ale nie mają związku $\mathrm{z}$ jej zadaniami. Są to takie funkcje wspierające jak, finanse, gospodarka materiałowa czy zarządzanie zasobami ludzkimi. Generalnie rzecz biorąc funkcje wspierające powinny być określane przez podmioty zewnętrzne takie jak urzędy skarbowe, inspekcje pracy, inspekcje RODO, ubezpieczalnie itd. Usługi outsourcingu także należą do funkcji wspierających, choć może się zdarzyć, że jakaś część funkcji podstawowych może być realizowana także w tym trybie np. zewnętrzne skanowanie dokumentacji. Na ciekawy aspekt outsourcingu na etapie wstępnym archiwizacji, stanowiącym istotny krok w kierunku dalszego opracowania, lub nawet je zastępujący zwrócili uwagę Krzysztof i Sylwia Stryjkowscy ${ }^{16}$.

Precyzyjne zdefiniowanie funkcji podstawowych jest fundamentem skutecznego i transparentnego zarządzania, w konsekwencji czego wytwarzana jest informacja obrazująca działalność jednostki organizacyjnej w jasnym i wyraźnym kontekście, tworząc elementy spójnego i klarownego opisu archiwalnego, na czym nie tylko nam, archiwistom, zależy.

A. Laszuk, Archiwizacja jako klucz do dobrego zarządzania. Międzynarodowy zestaw narzędzi, [w:] Archiwa źródła, historia prace ofiarowane w siedemdziesiąte urodziny Profesora Władysława Stępniaka, red. E. Rosowska i H. Wajs, Warszawa 2018, s. 37-50.

${ }^{15}$ Szczegółowo zostały one omówione w module 6 i 7, L'archivage, clé d’une bonne gouvernance.

${ }^{16}$ K. Stryjkowski, S. Stryjkowska, Ustugi archiwalne i outsourcing oraz ich wptyw na działalność i zasób archiwów, „Archeion”, t. 118, 2017 s. 48-68. 
Powyższe uwagi nie oznaczają, że zagadnienie funkcji jest ignorowane przez polską archiwistykę. Zgodnie z jej dorobkiem teoretycznym i wskazówkami zalecanymi przez Naczelnego Dyrektora Archiwów Państwowych, środki ewidencyjno-informacyjne, sporządzane w polskich archiwach, zawierają dane o funkcjach i zadaniach wykonywanych przez twórców materiałów archiwalnych, ale są to zazwyczaj jedynie elementy wstępu do inwentarza. W systemach informatycznych, gromadzących obecnie opisy zasobu archiwalnego, umieszczane są one jako fragmenty większych elementów opisu. Jednak polski słownik archiwalny nie zdefiniował terminu „funkcja”. Termin ten nie został też użyty w tezaurusie archiwistyki, w którym Stanisław Nawrocki zaproponował systematykę czynności archiwalnych, o czym poniżej ${ }^{17}$.

Encyklopedia archiwistyki, opracowana w drugiej dekadzie XXI stulecia, poświęca funkcji kilkustronicowe hasło. Jego autorka, Fiorella Foscarini, zwraca uwagę na to, iż zrozumienie funkcji pełnionej przez twórcę dokumentacji jest kluczowe dla zrozumienia nie tylko treści źródeł, ale i kontekstu ich tworzenia i zarządzania ${ }^{18}$. Na znaczenie tego aspektu systemu informacji archiwalnej zwracał też uwagę Adam Baniecki, pisząc o znaczeniu identyfikacji funkcji i wypełniających je jednostek w różnych okresach historycznych. Miałoby to na celu „stworzenie możliwości docierania do zasobu, bez konieczności znajomości nazwy twórcy czy nazwy zespołu."19. Przecież to właśnie w wyniku wykonywania działalności, funkcji, zadań ${ }^{20}$ przez osoby i podmioty powstaje różnorodna dokumentacja, przechowywana później pieczołowicie w archiwach historycznych. Rodzaje i formy dokumentacji oraz zawarte w niej informacje mają ścisły związek z określoną aktywnością, o czym wiedzą doświadczeni badacze ${ }^{21}$.

17 S. Nawrocki, Tezaurus archiwistyki, Warszawa 1984,

${ }^{18}$ Encyclopedia of Archival Science, ed. L. Duranti, P. C. Franks, Lanham, MD, 2015, s. 215.

19 A. Baniecki, Krajowe adaptacje międzynarodowych standardów archiwalnych, „Archeion" 2011, t. 112, s. 177.

${ }^{20}$ Stosowane są różne terminy na określenie form aktywności istniejących podmiotów - funkcje, działania, zadania. Tę różnorodność zauważyć można choćby w tytule czwartego ze standardów opisu Międzynarodowej Rady Archiwów, który w wersji roboczej brzmiał International Standard for Activities-Functions ISAF. W niniejszym tekście terminy te używane są zamiennie, podobnie jak w innych publikacjach, por. K. Stryjkowski, O starych i nowych funkcjach archiwum, [w:] Nowe funkcje archiwów, red. I. MamczakGadkowska, K. Stryjkowski, Poznań 2015, s. 11.

${ }^{21}$ Warto zwrócić uwagę na przykładowe opracowania, wskazujące na związki niektórych rodzajów dokumentacji z jej twórcami, o zmiennej w czasie organizacji, np. M. Korejwo, Ewidencja ludności i dowody osobiste. Akta spraw: formy, postaci, podstawy prawne 
Międzynarodowe środowisko archiwistów poświęca więc zagadnieniu funkcji coraz więcej uwagi, co znalazło odzwierciedlenie w projekcie nowego modelu opisu Records in Contexts (RiC) ${ }^{22}$. Na model ten składa się 14 jednostek opisu. I tylko cztery z nich dotyczą materii do tej pory podstawowej w systemach informacji - materiałów archiwalnych [obecny ISAD (G)]: dokument, część dokumentu, zbiór dokumentów i forma dokumentacji ${ }^{23}$. Siedem, czyli połowa, dotyczy twórcy lub zarządcy dokumentacji (,agenta”)24: agent (aktotwórca), occupation (profesja), position (stanowisko), function (funkcja), abstract (abstrakt), activity (działalność) i mandate (upoważnienie) ${ }^{25}$. Trzy ostatnie jednostki opisu, czyli data, miejsce i pojęcie, mimo iż przewidziano ich odrębne definiowanie, najczęściej występują jako cechy opisujące inne byty. W przypadku tych jednostek opisu przewiduje się stosowanie słowników kontrolowanych.

W związku z tym trendem rozwoju światowej archiwistyki, ewolucją modeli opisu archiwalnego oraz perspektywą włączenia do polskiego Zintegrowanego Systemu Informacji Archiwalnej nie tylko opisów twórców, ale i opisów pełnionych przez nich funkcji jako punktów dostępu do informacji, autorzy niniejszego tekstu postanowili przyjrzeć się funkcjom im najbliższym czyli wypełnianym przez archiwa państwowe. Za podstawę analizy przyjęli akty normatywne odnoszące się do archiwów i dokumentację o charakterze sprawozdawczym w ich brzmieniu obowiązującym w połowie 2020 r.: ustawę o narodowym zasobie archiwalnym i archiwach (ustawa archiwalna) ${ }^{26}$, jednolity rzeczowy wykaz akt (jrwa) ${ }^{27}$,

1928-1990, „Archeion” 2016, t. 117, s. 189-214; U. Markiewicz, Państwowy zasób geodezyjny $i$ kartograficzny $w$ zasobie Archiwum Państwowego w Szczecinie - zagadnienia archiwotwórcze i problemy opracowania, „Archeion” 2016, t. 117, s. 215-230.

${ }^{22}$ Projekt dostępny na stronie internetowej https://www.ica.org/en/egad-ric-conceptual-model (dostęp 10.07.2020). Por. A. Laszuk, Dokumenty w kontekstach: projekt standardu, „Archiwista Polski” 2016, nr 4, s. 89-94; B. Nowożycki, Records in Context. Omówienie nowego standardu opisu archiwalnego, „Archeion” 2018, t. 119, s. 297-316.

${ }^{23}$ Documentary form - Nowożycki tłumaczy to jako „forma dyplomatyczna”, B. Nowożycki, dz. cyt., s. 306.

${ }^{24}$ Obecnie odpowiada to jednostkom i elementom opisu określonym przez ISAAR (CPF) i ISDF, a zarazem ISDIAH.

${ }^{25}$ Tłumaczenia terminów podane za B. Nowożycki, dz. cyt., s. 303-305.

${ }^{26}$ Ustawa z dnia 14 lipca 1983 r. o narodowym zasobie archiwalnym i archiwach, t.j. Dz.U. 2020, poz.164.

27 Zarządzenie Nr 46 Naczelnego Dyrektora Archiwów Państwowych z dnia 19 grudnia 2019 r. zmieniające zarządzenie w sprawie instrukcji kancelaryjnej, jednolitego rzeczowego wykazu akt i instrukcji w sprawie organizacji i zakresu działania archiwów zakładowych w archiwach państwowych, https://ndap.bip.gov.pl/dziennik-urzedowy/ dziennik_urzedowy_2019.html (dostęp 10.07.2020). 
wzór sprawozdania z działalności ${ }^{28}$ oraz Strategię Archiwów Państwowych na lata 2010-202029. Zaniechano na tym etapie analizy statutów i regulaminów organizacyjnych archiwów państwowych, wychodząc z założenia, że niezależnie od wielkości i organizacji archiwum, podstawowe funkcje mogą i powinny być wypełniane. Jak stwierdza Foscarini, funkcje są na ogół bardziej stabilne niż struktury, a relacja dokumentów i funkcji ma charakter stały ${ }^{30}$.

Fundamentalne znaczenie powinna mieć ustawa archiwalna. Jej artykuł 23. wymienia siedem podstawowych funkcji stanowiąc, że działalność archiwalna to: gromadzenie, ewidencjonowanie, przechowywanie, opracowanie, zabezpieczenie i udostępnianie materiałów archiwalnych oraz prowadzenie działalności informacyjnej. Szerszy jest zakres działania archiwów państwowych, przedstawiony w artykule 28. ust. 1. ustawy archiwalnej. Oprócz siedmiu powyższych funkcji wyznacza ona dwa inne działania specyficzne dla tych archiwów czyli kształtowanie państwowego zasobu archiwalnego (pkt 1) i kontrolę postępowania z materiałami archiwalnymi (pkt 3), która faktycznie stanowi część tej jednej pierwszorzędnej funkcji, jaką jest kształtowanie zasobu archiwalnego. Pozostałe działania, wymienione w art. 28. ust. 1 ustawy nie są zastrzeżone dla archiwów i mogą być wykonywane przez wiele innych podmiotów. Są nimi: wydawanie uwierzytelnionych odpisów, wypisów, wyciągów i reprodukcji przechowywanych materiałów, a także wydawanie zaświadczeń na podstawie tych materiałów (pkt 4); prowadzenie prac naukowych oraz wydawniczych w dziedzinie archiwistyki i dziedzin pokrewnych (pkt 5); popularyzacja wiedzy o materiałach archiwalnych i archiwach (pkt 6). Ostatni punkt dotyczy wykonywania zadań określonych w przepisach o narodowym zasobie archiwalnym i archiwach.

Warto zaznaczyć, że ustawa nie definiuje tych funkcji. Polski stownik archiwalny, którego ostatnia wersja o prawie 10 lat poprzedza ustawę archiwalnąą, zawiera definicje jedynie części z nich. I mimo iż zakres i sposób ich wykony-

${ }^{28}$ Zarządzenie Nr 8 Naczelnego Dyrektora Archiwów Państwowych z dnia 30 listopada 2007 r. w sprawie zasad opracowania i terminu składania rocznego sprawozdania opisowego z działalności archiwum państwowego oraz przedkładania cząstkowych sprawozdań statystycznych (ze zm.), RNDAP, WOU-030-1/07.

${ }^{29}$ Wprowadzona komunikatem nr 1/2010 Naczelnego Dyrektora Archiwów Państwowych z dnia 23 grudnia 2010 r. https://www.archiwa.gov.pl/pl/o-nas/strategia-archiw\%C3\%B3w-pa\%C5\%84stwowych (dostęp 10.07.2020].

${ }^{30}$ Encyclopedia of Archival Science, s. 217.

${ }^{31}$ Polski słownik archiwalny, red. W. Maciejewska, Warszawa 1974. 
wania od 1974 r. uległy ewolucji, terminy słownikowe mogłyby stanowić jedną z podstaw słownika funkcji archiwów. Warto więc przypomnieć te definicje.

Kształtowanie narastającego zasobu archiwalnego: oddziaływanie władz archiwalnych na twórców zespołów poprzez instruktaż i nadzór w celu prawidłowego zabezpieczenia materiałów archiwalnych o wartości historycznej ${ }^{32}$. Kolejna definicja, nadzór nad narastającym zasobem archiwalnym, wskazuje wręcz czynniki składające się na tę funkcję: „ogół czynności kontrolnych wykonywanych przez władze archiwalne w oparciu o przysługujące im uprawnienia w stosunku do twórców zespołów w zakresie stosowania przez nich właściwego sposobu klasyfikacji, systematyzacji, kwalifikacji, brakowania, przechowywania i ewidencjonowania materiałów archiwalnych"33.

Gromadzenie: uzupełnianie państwowego zasobu archiwalnego lub zasobu archiwum przez dopływy i nabytki materiałów archiwalnych. (fr. collecte, niem. Erfassen, Übernahme, ang. acquisition, accesioning, hiszp. recogida de fondos y/o documentos).

Opracowanie: dokonywanie czynności wchodzących w zakres porządkowania zespołu (zbioru) oraz sporządzanie do niego inwentarza ze wstępem, a niekiedy także innych pomocy archiwalnych. [ang. arrangement, description, fr. classement, description, intellectual control, niem. Ordnung, Erschließung, hiszp. organización, descripción, control intelectual ${ }^{34}$.

Udostępnianie: organizowanie przez archiwum w oparciu o obowiązujące przepisy form korzystania z materiałów archiwalnych. (ang. charge-out, fr. communication, niem. Benutzung, hiszp. difusión).

32 Wielojęzyczny słownik terminologii archiwistycznej zawiera definicję terminu nadzór archiwalny (prawo do): Wynikająca z przepisów odpowiedzialność archiwum lub programu zarządzania dokumentacją do nadzoru i proponowania rozwiązań w celu poprawy praktyki tworzenia dokumentacji, jej utrzymania i brakowania przez instytucje w ramach ich kompetencji (ang. inspection, right of; fr. contrôle scientifique et technique; niem. Inspektionsrecht; hiszp. derecho de inspección) https://www.archiwa.gov.pl/pl/ component/content/article/2-uncategorised/805-angielsko-polski-s\%C5\%82ownikterminologii-archiwistycznej-\%E2\%80\%93-projekt (dostęp 07.07.2020).

${ }_{33}$ Polski stownik archiwalny, s. 47-48.

${ }^{34} \mathrm{~W}$ słowniku zdefiniowane są także: porządkowanie zespołu (zbioru) archiwalnego - nadawanie prawidłowego układu materiałom archiwalnym w zespole (zbiorze) w oparciu o ustalenia metodyki archiwalnej. Na porządkowanie składają się zazwyczaj: segregacja, klasyfikacja, brakowanie i systematyzacja; inwentaryzacja archiwalna jedna z czynności wchodzących w zakres opracowywania zespołu (zbioru), polegająca na opisywaniu jednostek archiwalnych i sporządzaniu inwentarza zespołu (zbioru) archiwalnego. Polski słownik archiwalny, s. 64. 
Działalność informacyjna: administrowanie informacją, jej wykorzystanie i przekazywanie, oraz zastosowanie teorii i technik informacji naukowej do tworzenia, modyfikacji i rozwoju systemów do zarządzania informacją ${ }^{35}$.

Definicje trzech pozostałych zadań nie zostały ujęte w Polskim słowniku archiwalnym. Dwie można przytoczyć za najnowszym wielojęzycznym słownikiem terminologii archiwistycznej.

Przechowywanie: odpowiedzialność za opiekę nad dokumentami przez aktualnego przechowawcę (zależnie od miejsca przechowywania). Opieka nie zawsze wiąże się z prawem własności i prawem do kontroli dostępu do dokumentacji (ang. custody, fr. conservation, niem. Verwahrung, dauernde Aufbewahrung, hiszp. custodia).

Zabezpieczanie: całokształt procesów i czynności podejmowanych w celu zachowania trwałości i ochrony dokumentów przed uszkodzeniem lub degradacją, a także w postępowaniu z uszkodzonymi lub zniszczonymi dokumentami. Zabezpieczenie może także obejmować przenoszenie danych/informacji na inny nośnik, np. mikrofilm. patrz także: konserwacja (ang. preservation, fr. conservation, préservation, niem. Bestandserhaltung, Aufbewahrung, hiszp. conservación).

Jedynie ewidencjonowanie nie jest zaś terminem zdefiniowanym w słownikach specjalistycznych. Jest to termin powszechny, rozumiany jako prowadzenie ewidencji, sporządzanie i aktualizacja środków ewidencyjnych ${ }^{36}$. Można przyjąć, że pojęcie ewidencjowanie jest ściśle związane ze stanem skarbowym, orientacją w stanie posiadania, w naszym wypadku zasobu archiwalnego. Nie jest zatem jego głównym zadaniem dostarczanie informacji dla zadania/funkcji udostępniania, to ostatnie przynależne jest opracowaniu. Stan skarbowy, ewidencyjny może ulegać zmianom na różne sposoby, takie jak: ilościowy (brakowanie $\mathrm{z}$ zasobu, łączenie lub dzielenie jednostek archiwalnych w trakcie opracowania) lub jakościowy (zmiana miejsca jednostki w zespole skutkiem opracowania lub przesygnowania). W każdym z tych przypadków afiliacja informacji i jej źródła ulega zmianie, a to jest niedopuszczalne w informacji naukowej czy szerzej w funkcji udostępniania. Dla realizacji funkcji udostępniania konieczna jest realizacja funkcji opracowania, która gwarantuje trwałość metadanych o informacji.

Wykonywanie powyższych, wyznaczonych przez ustawę archiwalną funkcji $\mathrm{w}$ praktyce powinno znaleźć odbicie w dokumentacji wytwarzanej przez ar-

35 Wielojęzyczny słownik zawiera termin zarządzanie informacją (ang. information management; fr. gestion de l'information; niem. Informationsverwaltung, hiszp. gestión de la información).

${ }^{36}$ Por.: Słownik języka polskiego, t. 2, D-G, Warszawa 1960, s.775. 
chiwa państwowe, a ta ujęta jest od dziesiątków lat w systemy klasyfikacyjne. W najnowszym jednolitym rzeczowym wykazie akt, dokumentacja specyficzna dla działalności archiwów opisana została w klasach 4-8. Klas obejmujących funkcje podstawowe jest nieco więcej niż klas obejmujących funkcje wspierające (5:4), lecz szczegółowych haseł klasyfikacyjnych na określenie dokumentacji specyficznej dla działalności podstawowej jest w sumie mniej ${ }^{37}$. Mimo to większość zadań ustawowych znalazła odzwierciedlenie już w hasłach pierwszego rzędu. Kształtowaniu zasobu archiwalnego poświęcona jest cała klasa 4. Klasa 5. obejmuje dokumentację wytwarzaną w trakcie wypełniania trzech zadań: gromadzenie, opracowanie i ewidencjonowanie. W haśle klasy 6. ujęto zabezpieczanie i udostępnianie. Dokumentacja zadań związanych z przechowywanie nie ma w jrwa wyraźnie wskazanego miejsca, podobnie jak nie ujęto tego terminu w słowniku archiwalnym. Działalność informacyjna również nie ma obecnie odpowiednika w klasie pierwszego rzędu jrwa. Klasa 7. odnosi się do ustawowych zadań archiwów państwowych, tzn. działalność naukowa i popularyzatorska, nie stanowiących jednak wyłącznej ich domeny. Klasa 8. zawiera w sobie kilka funkcji lub podfunkcji, a podstawą jej wyodrębnienia była forma tej działalności, nie jej cel i zakres.

Budowa i brzmienie haseł niższych rzędów są jeszcze bardziej niejednorodne. Określają one funkcje, podfunkcje, zadania, formy działalności, a czasem stanowią je nazwy typów dokumentacji. Mimo to można uznać, że jrwa stanowić mógłby jeden z podstawowych punktów wyjścia, skąd czerpać można by było dane do typologii i systematyki jednostek opisu proponowanych w projekcie RiC, takich jak: forma dokumentacji, occupation, position, function, function (abstract) i activity.

Trzeba jednakże zauważyć, że zadania i czynności należące do jednej funkcji nie są w jrwa archiwów ściśle rozgraniczone. I nie wynika to tylko z tego, że ustawa archiwalna określa 8 funkcji specyficznych i kilka spełnianych nie tylko przez archiwa państwowe, zaś klas merytorycznych dla funkcji podstawowych w wykazie jest tylko sześć. Można przyjrzeć się przykładowym dwóm funkcjom, kształtowaniu zasobu archiwalnego i opracowaniu materiałów archiwalnych, bardzo różnie rozpisanym na hasła klasyfikacyjne. Klasa 4 - „Kształtowanie zasobu archiwalnego i nadzór nad nim” ma tytuł powtarzający nazwę funkcji

37 Zamiarem autorów nie jest ocena sposobu budowania wykazu akt, lecz spojrzenie na ten dokument z punktu widzenia pomocniczości do wyodrębnienia funkcji i zadań oraz rodzajów dokumentacji, które mogą stać się jednostkami opisu w systemie informacji archiwalnej, budowanym zgodnie z założeniami RiC. 
podanej w ustawie. Struktura tej klasy jest najbardziej spójna i określa kompleks działań składających się na jej wykonywanie. Niektóre hasła drugiego rzędu wskazują jej podfunkcje, np. „Wartościowanie dokumentacji” (klasa 40). W ramach tej klasy ujęto jednak nie tylko wartościowanie dokumentacji („Brakowanie dokumentacji niearchiwalnej podmiotów państwowych i samorządowych" i „Ocena wartości archiwalnej dokumentacji”), ale i szeroko pojęte „wartościowanie” podmiotów („Ustalanie państwowych jednostek organizacyjnych i samorządowych jednostek organizacyjnych tworzących materiały archiwalne wchodzące do państwowego zasobu archiwalnego, prowadzenie ewidencji tych podmiotów i postępowanie w przypadku ich likwidacji”). Klasa 41 wyraźnie mówi o czynnościach nadzorczych, do których zaliczono: uzgadnianie przepisów kancelaryjnych i archiwalnych, kontrole, użyczanie i powierzanie materiałów archiwalnych. Różnorodne „Działania nagłe w zakresie nadzoru archiwalnego" dokumentują akta w ramach klasy 424. Trudno jednak uznać, że hasło klasy 425 - „Stan dokumentacji, w tym materiałów archiwalnych” stanowi określenie czynności, nie jest to też określenie typu dokumentacji, które zostały podane w polu uwagi - tzn. analizy, ankiety, spisy materiałów archiwalnych, sprawozdania z działalności archiwów, materiały organizacyjne.

Kolejne klasy nie są już tak konsekwentnie powiązane z typologią funkcji. Hasło 43 brzmi ogólnie i raczej uniwersalnie: „Relacje z podmiotami posiadającymi archiwa wyodrębnione”. Hasło 44 „Teczki zbiorcze dokumentacji nadzoru archiwalnego" stanowi natomiast odwrócenie sposobu patrzenia - nie przez pryzmat działalności na dokumentację, lecz jest przykładem zbioru dokumentacji jako jednostki opisu proponowanej w projekcie RiC.

Znacznie skromniej wygląda klasyfikacja dokumentacji powstającej w trakcie opracowania materiałów archiwalnych, a w zasadzie klasyfikacji tej nie ma. Jest tylko jedna klasa 530 - „Opracowanie materiałów archiwalnych”, mająca w polu uwagi: „sprawy zatwierdzania inwentarzy archiwalnych, informacje, instrukcje, oceny, recenzje, itp." Opracowaniu nie towarzyszy wszak wytwarzanie masowej dokumentacji kancelaryjnej, więc w tym przypadku jrwa nie wystarczy do dokładniejszego opisu tej funkcji. Wspomagać się można przy tym innymi dokumentami, na przykład tezaurusem archiwistyki, w którym opracowaniu przypisano 9 haseł niższego rzędu, w tym 5 zadań: formowanie jednostki archiwalnej, porządkowanie, inwentaryzacja, regestowanie i indeksowanie. $\mathrm{Na}$ porządkowanie składać się ma z kolei segregacja i systematyzacja, zaś przy inwentaryzacji występuje transkrypcja i transliteracja ${ }^{38}$.

${ }^{38}$ S. Nawrocki, dz. cyt., s 27. 
Kolejnym z dokumentów urzędowych, już nie konstytutywnym, ale zawierającym usystematyzowane informacje o działalności archiwów i sporządzanym cyklicznie, jest roczne sprawozdanie z działalności, którego wzór ustala naczelny dyrektor archiwów państwowych. Wzór ten ulega zmianom ${ }^{39}$, a ich analiza może być tematem odrębnego opracowania ${ }^{40}$. Opisując obecnie stan na połowę 2020 r. można stwierdzić niemałe różnice, nie tylko terminologiczne, między zakresem działalności wyznaczonym archiwom państwowym w ustawie archiwalnej, zasadom jej dokumentowania ustalonym w jrwa, a schematem sprawozdania rocznego. Wzór sprawozdania obejmuje dziewięć rozdziałów, których tytuły są hasłami rzeczowymi (1. Zasób archiwalny; 3. Narastający zasób archiwalny; 6. Publikacje; 8. Kadry i 7. Przechowalnictwo dokumentacji, oznaczające podfunkcję przechowywania, ale dokumentacji niearchiwalnej, częściowo traktowaną jako usługowa) lub nazwami działań (2. Techniczne zabezpieczenie zasobu; 4. Wykorzystanie zasobu archiwalnego; 5. Działalność naukowa), a w ostatnim 9. Sytuacja lokalowa, prace budowlane, fundusze pozabudżetowe, opisywane są zagadnienia materialne i finansowe, wiążące się z wypełnianymi funkcjami. Poza tym w większości rozdziałów oprócz danych merytorycznych o wykonanych zadaniach ${ }^{41}$ podawane są dodatkowe informacje. Dotyczą one kosztów działań ${ }^{42}$, wykonujących je osób ${ }^{43}$ lub form działania ${ }^{44}$.

39 Ostatnia, bardzo istotna zmiana nastąpiła po przekazaniu tekstu do redakcji. Wprowadzona została zarządzeniem nr 27 Naczelnego Dyrektora Archiwów Państwowych z dnia 30 października 2020 r. w sprawie organizacji procesu planowania i sprawozdawczości, wzorów formularzy planistycznych i sprawozdawczych oraz ustalenia terminów ich składania https://ndap.bip.gov.pl/dziennik-urzedowy/dziennik_urzedowy_2020. html (dostęp 02.11.2020].

40 Por. analiza wzoru sprawozdania statystycznego KN-1, H. Staszewska, O sprawozdawczości $w$ archiwach, czyli co chcielibyśmy wiedzieć, a czego nie dowiemy się ze sprawozdań? Próba analizy problemu i przyczynek do dyskusji, [w:] Nowe funkcje archiwów, s. 158-164.

${ }^{41}$ Lub o zadaniach niewykonanych, np. 3.1. Zaległości w przejmowaniu materiałów archiwalnych.

42 2.2. Koszty materiałowe konserwacji właściwej w roku sprawozdawczym; 2.7. Kwota nakładów na odpłatne zlecenia na wykonanie kopii zabezpieczających, 6.3. Nakłady na działalność wydawniczą. 7.2. Wartość kontraktów na przechowywanie dokumentacji niearchiwalnej.

43 3.3. Liczba etatów archiwum państwowego zaangażowanych w działalność nadzorczą, 5.11. Podnoszenie kwalifikacji kadry.

44 3.7. Przedsięwzięcia edukacyjne z zakresu kształtowania narastającego zasobu. 3.8.1. Współpraca z podmiotami z obszaru ewidencjonowanego niepaństwowego zasobu archiwalnego. 3.9. Konsultacje. 4.6. Współpraca z innymi placówkami. 4.7. Popularyzacja. 5.8. Projekty badawcze. 5.9. Współpraca w zakresie archiwoznawstwa. 
Rozdział Działalność naukowa obejmuje szeroki zakres niejednorodnych zagadnień - zawiera informacje o działaniu ciał kolegialnych wypełniających różne funkcje: kształtowania zasobu (5.5. Komisja archiwalnej oceny dokumentacji), gromadzenia zasobu (5.6. Komisja zakupu archiwaliów), opracowania zasobu (5.4. Komisja metodyczna); o zaangażowaniu pracowników poza archiwum (5.1. Centralne komisje $i$ zespoty międzyarchiwalne; 5.12. Udział we władzach instytucji naukowych $i$ kulturalnych), a także o publikacjach, którym poświęcony jest odrębny rozdział 6 . Poza właściwym nurtem rozważań należy stwierdzić, że sprawozdanie z działalności archiwum to nie tylko opis zadań wykonanych w jednym roku, ale i zbilansowany stan różnych jego elementów (np. wielkość zasobu, stan jego opracowania, wykaz pomocy archiwalnych), zaś po rozdziałach sprawozdawczych następuje Ogólna ocena warunków i wyników pracy archiwum ${ }^{45}$ oraz Przewidywane kierunki działań $i$ zakres prac archiwum $w$ następnym roku. Sprawozdanie uzupełniają załączniki.

Podobnie jak w przypadku jrwa, informacji o wypełnianiu niektórych funkcji ustawowych można dopatrywać się w tytułach podrozdziałów sprawozdania lub wręcz w jego treści. I podobnie jak jrwa, najpełniejszą informację można uzyskać zapoznając się z rozdziałem dotyczącym nadzoru nad narastającym zasobem archiwalnym. Niezwykle trudno jest natomiast czerpać ze sprawozdania dane dotyczące ewidencjonowania i przechowywania materiałów archiwalnych.

Tak skonstruowane sprawozdanie stanowić może pomoc uzupełniającą przy prowadzeniu analiz wykonywania tych funkcji przez archiwa państwowe, nie jest jednak dobrym źródłem do sporządzania systematyki funkcji, może jedynie wskazać zagadnienia istotne w danym okresie i pomóc formułować paradygmaty, odzwierciedlane w dokumentach typu strategia. Na zmieniające się funkcje archiwów w poscustodial era zwrócili uwagę m.in. Adrian Cunningham i Gianni Penzo Doria ${ }^{46}$. W Polsce o zmienności w czasie roli, zadań i statusu archiwów pisano już w pracach o charakterze naukowym i popularyzatorskim, dyskutowano na konferencjach i sympozjach ${ }^{47}$. Za najważniejsze wydarzenie

${ }^{45} \mathrm{~W}$ kilku miejscach sprawozdania zamieszczane są cząstkowe oceny i podsumowania, np. 3.2. Skuteczność nadzoru archiwalnego; 3.8. Szczególne obserwacje lub zagadnienia w dziedzinie kształtowania narastającego zasobu.

46 Encyclopedia of Archival Science, s. 274-275, 297-298.

47 Redaktorzy pamiętnika zjazdu Archiwistów w 2017 r. uczynili z funkcji archiwów jeden z elementów konstrukcyjnych publikacji. Wyodrębnili w nim rozdział „Funkcje i zadania archiwów", a w nim podrozdziały korespondujące mniej lub bardziej z ustawowym rozumieniem działalności archiwalnej. Wśród podrozdziałów są: infrastruktura, kształtowanie, gromadzenie, opracowanie, udostępnianie, konserwacja i zabezpieczanie 
uznać można konferencję „Nowe funkcje archiwów”, która odbyła się w 2014 r. w Poznaniu ${ }^{48}$. Redaktorzy materiałów pokonferencyjnych piszą we wstępie wręcz o „starych” i „nowych” funkcjach, także ujmując te przymiotniki w cudzysłów. W tytule tekstu autorstwa Krzysztofa Stryjkowskiego nie ma cudzysłowów, autor omawia w nim bowiem ewolucję rozumienia funkcji, przedstawianego w aktach prawa i literaturze polskiej i światowej ${ }^{49}$. Do funkcji archiwów państwowych zaliczył on nie tylko te specyficzne, ale i inne wskazane w art. 28 ustawy. To i pozostałe przedstawione na konferencji wystąpienia były efektem analiz i obserwacji funkcji dłużej realizowanych, bądź będących reakcją na doraźne, ale wyraźne zapotrzebowanie polityczne lub społeczne. Podobne przyczyny leżą właśnie u podstaw formułowania wzorów planów, sprawozdań czy strategii, które obowiązują zazwyczaj krótko i ulegają zmianom. Do celów budowy bardziej stabilnych struktur zasobu archiwalnego, opartych zazwyczaj na układzie kancelaryjnym, wskazane byłoby jednak opracowanie bardziej uniwersalnego słownika określającego funkcje twórców zasobu, w tym archiwów państwowych.

Powyższe rozważania stanowią próbę podejścia do spojrzenia na działalność archiwów i tworzoną przez nie dokumentację zgodnie z duchem nowych trendów w międzynarodowej archiwistyce. Pytaniem otwartym jest, na ile spojrzenie przez pryzmat funkcji, z jednej strony na zasób archiwalny pod kątem rozwoju systemu informacji o nim, a z drugiej na dokumenty stanowiące i opisujące rzeczywistość archiwów, jest właściwą metodą podejścia do zagadnienia. Pytań jest na razie znacznie więcej. Jak długo trzeba byłoby czekać na efekty rzetelnej analizy, zdefiniowanie funkcji archiwów i ich zapisanie w aktach prawa, w dokumentach konstytuujących działalność archiwów, oraz próbę skonstruowania słownika funkcji na wzór AGIFT ${ }^{50}$ ? Czy jest to potrzebne i wykonalne,

oraz edukacja, popularyzacja, PR. Można to uznać za próbę klasyfikacji tematyki podejmowanej w referatach, choć ich lektura pokazuje, że nie w każdym zawarto elementy, które mogłyby wspomóc prace nad przygotowaniem systematyki funkcji typowych dla archiwów. Archiwa bez granic. Pamiętnik VII Powszechnego Zjazdu Archiwistów Polskich, Kielce, 20-21 września 2017 r., red. W. Chorążyczewski, K. Stryjkowski, Warszawa 2019.

${ }^{48}$ Nowe funkcje archiwów.

${ }^{49}$ K. Stryjkowski, dz. cyt., s. 11-19. Szerzej o zmianach w Polsce: R. Galuba, Nowe funkcje archiwów państwowych $w$ polskim prawie archiwalnym, [w:] Nowe funkcje archiwów, s. 49-65.

${ }^{50}$ W odniesieniu do archiwów można by założyć, że nie wszystkie wskazane w obecnej ustawie archiwalnej działania byłyby potraktowane równorzędnie. Za podstawowe funkcje mogłyby zostać uznane na przykład zabezpieczanie oraz udostępnianie zasobu archiwalnego. Na zabezpieczanie składałyby się podfunkcje: kształtowanie, gromadzenie, ewidencjonowanie, przechowywanie i konserwacja, zaś na udostępnianie: opracowy- 
jeśli się weźmie pod uwagę, że funkcje pełnią wszystkie podmioty, osoby prawne i fizyczne? Innymi słowami, czy możliwe byłoby przygotowanie i wdrożenie w Polsce modelu opisu zgodnego z założeniami Records in Contexts ${ }^{51}$ ?

Warto zaznaczyć, że model ten w pewnym zarysie bliski jest przedstawionemu w polskim tezaurusie archiwistyki, w „pomocy archiwalnej umożliwiającej indeksowanie źródeł informacji”, jak określił to Nawrocki ${ }^{52}$. Zestawione hierarchicznie terminy pogrupował on w zależności od tego, czego dotyczą czy teorii archiwistyki i nauk pokrewnych, czy metodyki, ukazując ich wzajemne relacje. I choć niewątpliwie sporo zmieniło się w ciągu ponad 30 lat w zakresie nośnika informacji, to już terminy w grupie „forma historyczna materiałów archiwalnych" uległy niewielkiej zmianie. Rozdział 3. tezaurusa Czynności archiwalne częściowo obejmuje systematyzację zadań związanych z materiałami archiwalnymi. Składa się on z pojęć zgrupowanych wokół haseł pierwszorzędnych: tworzenie akt w kancelarii (w tej grupie umieścił hasło „aktotwórca”), gromadzenie materiałów archiwalnych, wartościowanie, opracowywanie, ewidencja ${ }^{53}$, udostępnianie, reprodukcja, konserwacja i miejsce przechowywania materiałów archiwalnych. Struktura niektórych grup haseł byłaby bardzo pomocna przy określaniu bardziej szczegółowych jednostek funkcji, o ile takie prace byłyby podjęte.

W bliższej perspektywie z zainteresowaniem należy oczekiwać na kolejną strategię archiwów państwowych, sposób ujęcia w niej poszczególnych działań i funkcji oraz określenie ich priorytetów ${ }^{54}$. Przed dekadą Baniecki pisał: „Poważny niepokój budzi fakt, że aspekt rozwoju metodyki archiwalnej i ewentualnej

wanie (z zadaniami takimi jak porządkowanie i inwentaryzacja), działalność informacyjna, umożliwianie dostępu badaczom (do oryginałów w czytelni, do kopii w czytelni, publikowanie kopii online, reprografia na zamówienie, edycje źródeł), wykonywanie wyszukiwania przez archiwistów (z wydawaniem zaświadczeń, odpisów lub kopii).

${ }^{51}$ Archiwa fińskie już kilka lat przed ukazaniem się projektu modelu RiC opracowywały własny The Finnish Conceptual Model of Archival Description https://www.yumpu. com/en/document/view/36837292/the-finnish-conceptual-model-of-archival-description (dostęp 27.10.2020).

${ }^{52}$ S. Nawrocki, dz. cyt., s. 5.

${ }^{53} \mathrm{~W}$ tej grupie tylko hasło „skontrum” oznacza działanie, pozostałe są nazwami pomocy ewidencyjno-informacyjnych lub ich elementów, tamże, s. 29. W grupie reprodukcji nie ujęte zostało żadne działanie, tamże, s 30.

${ }^{54}$ Por. Zarządzenie Nr 14 Naczelnego Dyrektora Archiwów Państwowych z dnia 9 lipca 2020 r. w sprawie powołania Komitetu Sterującego do spraw strategii archiwów państwowych, https://ndap.bip.gov.pl/dziennik-urzedowy/dziennik_urzedowy_2020. html (dostęp 10.07.2020 r.) 
adaptacji standardów archiwalnych Międzynarodowej Rady Archiwów został całkowicie pominięty w Strategii Archiwów Państwowych na lata 2011-2020. Trudno sobie wyobrazić np. masowe udostępnianie materiałów archiwalnych online nie tylko bez rozwoju metodyki archiwalnej, ale i bez uwzględnienia znacznej już liczby innych, wymienionych wyżej, wymogów standaryzacyjnych ściśle ze sobą powiązanych." ${ }^{55} \mathrm{~W}$ trakcie obowiązywania tej strategii okazało się, że udostępnianie stało się absolutnym priorytetem, nawet jeśli nie zostało poprzedzone opracowaniem archiwaliów. W strategii na lata 2011-2020 główną rolę odgrywają bowiem „misja, wizja, cele strategiczne i operacyjne oraz mierniki realizowanych zadań”, które mają służyć „zaspokajaniu potrzeb informacyjnych państwa i społeczeństwa" ${ }^{56}$. I choć strategia powołuje się na ustawę o finansach publicznych jako swoją podstawę, we wstępie do niej wspomniane są właśnie ustawowe zadania archiwów państwowych jako podstawy formułowania celów. Sześć z wymienianych powyżej ośmiu funkcji podstawowych archiwów państwowych znalazło w jej tekście swoje odbicie, pominięto w niej ewidencjonowanie i opracowanie materiałów archiwalnych, które nadal figurują w ustawie archiwalnej. Są zadaniami wykonywanymi przez archiwistów wewnątrz archiwów, bardzo rzadko wymagają współpracy z innymi podmiotami. czy dodatkowych środków finansowych $\mathrm{Z}$ tych też powodów nie powstaje $\mathrm{w}$ ich wyniku obfita dokumentacja kancelaryjna, ale osiągnięte $\mathrm{w}$ ich wyniku zapisy dokumentacyjne, pomoce ewidencyjno-informacyjne, stanowią elementy systemu informacji o zasobie archiwalnym. Mają więc znaczenie ponadczasowe.

\section{Bibliografia}

Baniecki, Adam, tłum. ISDF. Międzynarodowy standard opisu funkcji. Warszawa: Naczelna Dyrekcja Archiwów Państwowych, 2017. https://www.archiwa.gov.pl/files/ISDF.pdf.

Baniecki, Adam. „Krajowe adaptacje międzynarodowych standardów archiwalnych”. Archeion 112 (2011): 173-90.

Baniecki, Adam, i Rafał Raczyński. „Raport końcowy z realizacji projektu badawczego wdrożenia systemu Access to Memory AtoM w Archiwum Państwowym we Wrocławiu w latach 2012-2016 sporządzony pod kątem optymalizacji funkcji archiwów

55 A. Baniecki, Krajowe adaptacje, s. 188.

56 Strategia archiwów państwowych na lata 2010-2020. Załącznik do Komunikatu Nr 1/2010 Naczelnego Dyrektora Archiwów Państwowych z dnia 23 grudnia 2010 r., s. 1., https://www.archiwa.gov.pl/pl/component/content/category/39-strategia-archiw\%C3\%B3w-pa\%C5\%84stwowych (dostęp 10.07.2020). 
państwowych (Drugi raport)", b.d. DA.041.1.2020. Naczelna Dyrekcja Archiwów Państwowych.

Baniecki, Adam, i Anna Laszuk. „Archiwizacja jako klucz do dobrego zarządzania. Międzynarodowy zestaw narzędzi”. W Archiwa, źródła, historia: prace ofiarowane $w$ siedemdziesiąte urodziny Profesora Władysława Stępniaka, zredagowali Ewa Rosowska i Hubert Wajs, 37-50. Warszawa: Naczelna Dyrekcja Archiwów Państwowych, 2018.

Chorążyczewski, Waldemar, i Krzysztof Stryjkowski, red. Archiwa bez granic: pamiętnik VII Powszechnego Zjazdu Archiwistów Polskich. Kielce, 20-21 września 2017 r. Warszawa: Stowarzyszenie Archiwistów Polskich, 2019.

Doroszewski, Witold, red. Słownik języka polskiego. T. 2. Warszawa: Wiedza Powszechna, 1960.

Duranti, Luciana, i Patricia C. Franks, red. Encyclopedia of archival science. Lanham, Maryland: Rowman \& Littlefield, 2015.

The Finnish Conceptual Model of Archival Description. Dostęp 27.10.2020. https://www. yumpu.com/en/document/read/36837292/the-finnish-conceptual-model-of-archival-description.

Galuba, Rafał. „Nowe funkcje archiwów państwowych w polskim prawie archiwalnym”. W Nowe funkcje archiwów, zredagowali Irena Mamczak-Gadkowska i Krzysztof Stryjkowski, 49-65. Poznań: Instytut Historii UAM, 2015.

Korejwo, Mariusz. „Ewidencja ludności i dowody osobiste. Akta spraw: formy, postaci, podstawy prawne 1928-1990". Archeion 117 (2016): 189-214.

Laszuk, Anna. „Dokumenty w kontekstach: projekt standardu”. Archiwista Polski 21, nr 4 (2016): 7-18.

Laszuk, Anna. „Europejski Portal Archiwalny - efekt współpracy i działania opartego na standardach międzynarodowych". W Archiwa Polski i Europy: wspólne dziedzictwo różne doświadczenia $=$ Polish and European archives ; shared heritage - dissimilar experiences, zredagowała Alicja Kulecka, 23-34. Warszawa: Wydawnictwa Uniwersytetu Warszawskiego, 2017.

Laszuk, Anna. „Zagadnienia teoretyczne i praktyczne a rekomendacje Centralnej Komisji Metodycznej kadencji 2013-2016". W Metodyka i standardy opracowania archiwalnego: rzeczywistość i potrzeby, zredagowali Irena Mamczak-Gadkowska i Krzysztof Stryjkowski, 21-30. Poznań: Instytut Historii UAM, 2019.

Maciejewska, Wanda, red. Polski słownik archiwalny. Warszawa; Łódź: Państwowe Wydaw. Naukowe. Oddział, 1974.

Mamczak-Gadkowska, Irena, i Krzysztof Stryjkowski, red. Nowe funkcje archiwów. Poznań: Instytut Historii UAM, 2015.

Markiewicz, Urszula. „Państwowy zasób geodezyjny i kartograficzny w zasobie Archiwum Państwowego w Szczecinie - zagadnienia archiwotwórcze i problemy opracowania". Archeion 117 (2016): 215-230.

Naczelny Dyrektor Archiwów Państwowych. „Strategia archiwów państwowych na lata 2010-2020. Załącznik do Komunikatu Nr 1/2010 Naczelnego Dyrektora Archiwów Państwowych z dnia 23 grudnia 2010 r.”. Dostęp 10.07.2020. https://www.archiwa. gov.pl/pl/component/content/category/39-strategia-archiw\%C3\%B3w-pa\%C5\%84stwowych. 
Naczelny Dyrektor Archiwów Państwowych. „Zarządzenie Nr 8 Naczelnego Dyrektora Archiwów Państwowych z dnia 30 listopada 2007 r. w sprawie zasad opracowania i terminu składania rocznego sprawozdania opisowego z działalności archiwum państwowego oraz przedkładania cząstkowych sprawozdań statystycznych”. WOU030-1/07. Naczelna Dyrekcja Archiwów Państwowych.

Naczelny Dyrektor Archiwów Państwowych. „Zarządzenie Nr 46 Naczelnego Dyrektora Archiwów Państwowych z dnia 19 grudnia 2019 r. zmieniające zarządzenie w sprawie instrukcji kancelaryjnej, jednolitego rzeczowego wykazu akt i instrukcji w sprawie organizacji i zakresu działania archiwów zakładowych w archiwach państwowych”. Dostęp 10.07.2020. https://ndap.bip.gov.pl/dziennik-urzedowy/ dziennik_urzedowy_2019.html.

Naczelny Dyrektor Archiwów Państwowych. „Zarządzenie Nr 14 Naczelnego Dyrektora Archiwów Państwowych z dnia 9 lipca 2020 r. w sprawie powołania Komitetu Sterującego do spraw strategii archiwów państwowych - tekst”. Dostęp 10.07.2020. https://ndap.bip.gov.pl/dziennik-urzedowy/dziennik_urzedowy_2020.html.

Naczelny Dyrektor Archiwów Państwowych. „Zarządzenie Nr 27 Naczelnego Dyrektora Archiwów Państwowych z dnia 30 października 2020 r. w sprawie organizacji procesu planowania i sprawozdawczości, wzorów formularzy planistycznych i sprawozdawczych oraz ustalenia terminów ich składania". Dostęp 10.07.2020. https://ndap.bip. gov.pl/dziennik-urzedowy/dziennik_urzedowy_2020.html.

National Archives of Australia. „Australian Governments' Interactive Functions Thesaurus (AGIFT)”. Dostęp 8.08.2020. https://data.naa.gov.au/def/agift/AGIFT.html.

Nawrocki, Stanisław. Tezaurus archiwistyki. Warszawa: Naczelna Dyrekcja Archiwów Państwowych, 1984.

Nowożycki, Bartosz. „Records in Context. Omówienie nowego standardu opisu archiwalnego". Archeion 119 (2018): 297-316.

Overview of Classification Tools for Records Management. Canberra: National Archives of Australia, July 2003. https://www.naa.gov.au/sites/default/files/2019-10/classifcation-tools.pdf.

„Rozporządzenie Rady Ministrów z dnia 24 grudnia 2007 r. w sprawie Polskiej Klasyfikacji Działalności (PKD).” Dziennik Ustaw Rzeczpospolitej Polskiej, nr 251, poz. 1885 (2007).

Staszewska, Hanna. „O sprawozdawczości w archiwach, czyli co chcielibyśmy wiedzieć, a czego nie dowiemy się ze sprawozdań? Próba analizy problemu i przyczynek do dyskusji". W Nowe funkcje archiwów, zredagowali Irena Mamczak-Gadkowska i Krzysztof Stryjkowski, 158-64. Poznań: Instytut Historii UAM, 2015.

Strategies for Documenting Government Business: the DIRKS Manual, July 2018. https:// www.opengov.nsw.gov.au/publications/17383.

Stryjkowski, Krzysztof. „O starych i nowych funkcjach archiwum”. W Nowe funkcje archiwów, zredagowali Irena Mamczak-Gadkowska i Krzysztof Stryjkowski, 11-19. Poznań: Instytut Historii UAM, 2015.

Stryjkowski, Krzysztof, i Sylwia Stryjkowska. „Usługi archiwalne i outsourcing oraz ich wpływ na działalność i zasób archiwów". Archeion 118 (2017): 48-68.

„Ustawa z dnia 4 września 1997 r. o działach administracji rządowej.” Dziennik Ustaw Rzeczpospolitej Polskiej, poz. 1220 (2020). 